\title{
Reaction of sugarcane genotypes to brown and to orange rust by leaf whorl inoculation
}

\section{Lívia Maria Lemos Hoepers ${ }^{1}$ (D) Ana Cristina Grade Fiori-Tutida ${ }^{1}$ Lucimeris Ruaro $^{1}$ (D) Renata Faier Calegario ${ }^{1}$ (D) Ricardo Augusto Oliveira ${ }^{1}$ (iD) Henrique da Silva Silveira Duarte ${ }^{*^{*}}$ (D)}

'Departamento de Fitotecnia e Fitossanidade, Universidade Federal do Paraná (UFPR), 80035-050, Curitiba, PR, Brasil. E-mail: henriqueduarte@ufpr.br. *Corresponding author.

ABSTRACT: In this research eleven sugarcane genotypes were classified in relation to their resistance to brown rust, and eleven to their resistance to orange rust. Artificial inoculation was carried out in the leaf whorl of 165-day-old plants in the city of Paranavai, Paraná State, Brazil, in 2017. The evaluation was performed 30 days after inoculation, using a rating scale. Among the genotypes tested for brown rust, four were classified as susceptible, six as moderately susceptible and one presented moderate resistance. For orange rust, three genotypes were classified as susceptible, seven as moderately susceptible and one as moderately resistant. The evaluation and classification of the reaction of sugarcane genotypes to the rusts is an important tool that assist in preliminary trials and selection of promising genotypes for more advanced stages of breeding programs and provides information to producers on the choice of cultivars to be planted.

Key words: Saccharum spp., Puccinia melanocephala, Puccinia kuehnii, classification, resistance.

Reação de genótipos de cana-de-açúcar às ferrugens marrom e alaranjada por inoculação no cartucho foliar

RESUMO: Neste trabalho onze genótipos de cana-de-açúcar foram classificados em relação à sua resistência à ferrugem marrom, e onze quanto à resistência à ferrugem alaranjada. Foi realizada a inoculação no "cartucho foliar" de colmos com 165 dias, no município de Paranavaí, PR, em 2017. A avaliação foi feita aos 30 dias após a inoculação, utilizando uma escala de notas. Dos genótipos avaliados para ferrugem marrom, quatro foram classificados como suscetiveis, seis como moderadamente suscetiveis e um apresentou resistência moderada. Para a ferrugem alaranjada, três genótipos foram classificados como suscetíveis, sete como moderadamente suscetíveis e um como moderadamente resistente. A avaliação e classificação da reação de genótipos de cana-de-açúcar às ferrugens é uma ferramenta importante que auxilia em ensaios preliminares, na escolha de genótipos promissores para fases mais avançadas dos programas de melhoramento além de fornecer informações aos produtores na seleção das cultivares que serão plantadas.

Palavras-chave: Saccharum spp., Puccinia melanocephala, Puccinia kuehnii, classificação, resistência.

Sugarcane is an important crop in Brazil, with a production estimated in 747 million tons in the $2017 / 2018$ harvest, which corresponds to about $39 \%$ of the world total, giving the country the title of largest world producer (FAOSTAT, 2020). Yield is influenced by factors such as crop genetic characteristics, climatic factors, soil physicochemical characteristics, nutrient availability, pests, weeds and diseases (GILBERT et al. 2006; LIMA et al. 2017).

Among the diseases, the rusts stand out. Brown rust, caused by the fungus Puccinia melanocephala Syd. \& P. Syd., was first reported in
Brazil in the municipality of Capivari (SP), in 1986, and spread rapidly throughout the other producing regions of the country (AMORIM et al. 1987). It promotes reduction of photosynthetic area causing delay in plant development in susceptible cultivars. Orange rust, caused by Puccinia kuehnii (W. Krüger) E. J. Butler, was first observed in Brazil in 2009, when it affected the production of three highly susceptible cultivars, SP89-1115, RB72454 and SP84-2025, corresponding to $10 \%$ of sugarcane plantations in the country at the time (BARBASSO et al. 2010). Like P. melanocephala, the fungus produces pustules on the leaf surface, reducing 
photosynthetic activity, production and quality of the final product (ZHAO et al. 2011).

Although, fungicide application is employed as an emergency technique, the main control method of sugarcane rusts is the use of resistant cultivars (ROTT et al. 2016). For such a control measure to be adopted efficiently, it is necessary to know the level of genotype resistance to diseases. Most of the studies on classification of Brazilian genotypes regarding their resistance to diseases are dedicated to orange rust (ARAÚJO et al. 2013; KLOSOWSKI et al. 2015; CHAPOLA et al. 2016; URASHIMA et al. 2018), with those focusing on brown rust being prior to the arrival of Puccinia kuehnii in the country (IDO et al. 2006). Thus, the objective of this study was to verify the reaction of sugarcane genotypes to brown and orange rust in terms of their resistance using leaf whorl inoculation technique.

Two experiments (one experiment for each disease) were conducted in 2016/17 for evaluation of genotypes in relation to resistance to brown rust and to orange rust in an experimental area in the municipality of Paranavaí, Paraná, Brazil (2305' S; 52²6’ W, 470 m asl), where a meteorological station was also installed to obtain climate data. The design used in both experiments was that of casualized blocks, with eleven treatments and four repetitions. The experimental unit consisted of two plants per genotype, spaced by 0.5 $\mathrm{m}$, and $2 \mathrm{~m}$ between treatments.

The genotypes evaluated for brown rust were: CTC-4, RB835486, RB966229, RB036065, RB036147, RB056388, RB106803, RB106811, RB106814, RB106819, RB106822; and for orange rust were: SP813250, RB72454, RB006629, RB036059, RB036145, RB036153, RB036163, RB056388, RB106803, RB106819, RB106822. Genotypes with known reaction to rust were included in the experiments. For brown rust, CTC-4 were used as susceptible standard; while RB106819 were used as resistance standards. For orange rust, susceptible standard were RB72454 and RB106819 as resistant standard. The other genotypes were chosen for their genetic potential of interest for the sugarcane improvement program.

The seedlings used came from individualized buds, which were planted in tubes containing commercial substrate and filter cake in a ratio of $1: 1$, on October 19, 2016, and kept in a greenhouse with irrigation by sprinkling until 60 days. After this period, the seedlings were manually transplanted to the field.

To obtain spore suspension for plant inoculation, urediniospores of P. melanocephala and P. kuehnii were collected in the experimental station of UFPR in Paranavaí, PR, using a vacuum pump and a glass collector at 15 days before inoculation by aspirating the surface of symptomatic leaves from susceptible cultivars, as described by SOOD et al. (2009) and stored in a freezer $\left( \pm 2{ }^{\circ} \mathrm{C}\right)$. The preparation of suspensions of the two rusts occurred in the same way, adding the spores in distilled water and shaking, in order to homogenize each suspension. The concentration was adjusted to $10^{4}$ viable spores $\mathrm{mL}^{-1}$ using a hemacytometer (Neubauer chamber, Optik Labor, Germany) (SOOD et al. 2009), adding 0.1\% of Tween 20 to the final volume of each suspension.

Inoculation was performed 105 days after transplanting the seedlings to the field, using $0.5 \mathrm{~mL}$ of suspension (water + spores + Tween 20), which was placed separately inside the leaf whorls of six individual stalks per replicate using a repeater pipette, being inoculated the three tallest stalks of each plant, which were identified for further evaluation by cutting $1 / 3$ of the top of the tallest leaves.

After 30 days of incubation, the inoculated leaves were evaluated, after they emerged from the whorl, where the symptoms were demonstrated as a band of pustules (in susceptible varieties). The symptoms of rust were assessed on the 0-4 scale (SOOD et al. 2009), with 0 - no symptoms, 1 - chlorotic flecks, 2 - orange-brown lesions, without sporulation, 3 - one to five pustules with sporulation (production of urediniospores), and 4 - six or more coalescent pustules with sporulation resulting in leaf necrosis. Treatments were analyzed based on the averages obtained in the field and classified according to the modified SOOD et al. (2013) scale, in which the genotypes with 0 - 1 notes were considered resistant; 1.1 - 2, moderately resistant; $2.1-3$, moderately susceptible and 3.1 - 4, susceptible.

The average temperature between the inoculation and plant evaluation (30 days) was 21.5 ${ }^{\circ} \mathrm{C}$, with a minimum of $15.5^{\circ} \mathrm{C}$ and a maximum of $25.7{ }^{\circ} \mathrm{C}$, and according to SANJEL et al. (2019) the ideal mean temperature for the development of both rusts is between 20 and $22.2{ }^{\circ} \mathrm{C}$. Average relative humidity of air during 30 days was $80 \%$, with accumulated precipitation of $177.6 \mathrm{~mm}$.

In the inoculated stalks, the symptoms were observed in bands of pustules well defined in the youngest leaf, the one that had contact with the urediniospores and its growth occurred between the inoculation and the evaluation. Based on the evaluation method proposed by SOOD et al. (2009), of the genotypes tested for brown rust, four were classified as susceptible, six as moderately susceptible and only one showed moderate resistance. Genotypes inoculated with $P$. kuehnii showed a similar pattern, three of them were classified as susceptible, seven as moderately susceptible and one as moderately resistant (Table 1). 
Table 1 - Brown and orange rust reaction of sugarcane genotypes based on leaf whorl artificial inoculation.

\begin{tabular}{|c|c|c|c|c|c|}
\hline Genotype & Score $^{*}$ & Reaction & Genotype & Score ${ }^{*}$ & Reaction \\
\hline RB966229 & 4.00 & Susceptible & RB036145 & 4.00 & Susceptible \\
\hline RB056388 & 3.96 & Susceptible & RB106803 & 3.96 & Susceptible \\
\hline RB835486 & 3.75 & Susceptible & SP81-3250 & 3.88 & Susceptible \\
\hline RB036065 & 3.25 & Susceptible & RB106822 & 3.04 & Moderately susceptible \\
\hline CTC-4 & 3.00 & Moderately susceptible & RB056388 & 3.00 & Moderately susceptible \\
\hline RB106803 & 3.00 & Moderately susceptible & RB72454 & 3.00 & Moderately susceptible \\
\hline RB106822 & 3.00 & Moderately susceptible & RB036163 & 2.96 & Moderately susceptible \\
\hline RB106811 & 2.92 & Moderately susceptible & RB036153 & 2.83 & Moderately susceptible \\
\hline RB106814 & 2.88 & Moderately susceptible & RB106819 & 2.83 & Moderately susceptible \\
\hline RB036147 & 2.75 & Moderately susceptible & RB036059 & 2.75 & Moderately susceptible \\
\hline RB106819 & 2.00 & Moderately resistant & RB006629 & 2.00 & Moderately resistant \\
\hline
\end{tabular}

*Mean score of 6 observations per treatment, according to the modified scale of SOOD et al. (2013) in which: scores of 0 - 1: resistant; 1.1 - 2: moderately resistant; 2.1 - 3: moderately susceptible and 3.1 - 4: susceptible.

In this study, it was observed that there are differences between the resistance levels of the genotypes for both brown and orange rust. SOOD et al. (2013) pointed out that the leaf whorl artificial inoculation of $P$. melanocephala and P. kuehnii can be performed even at seasons of the year when rust spores are not available in the field, because preserved urediniospores can be used. Because it is carried out in the field, leaf whorl inoculation may be a way to take advantage of routine trials of sugarcane breeding programs, in order to expose the genotypes to a condition favorable to the occurrence of the disease, assisting in preliminary trials and the selection of promising genotypes for more advanced phases of the programs (SOOD et al. 2009). In addition, the evaluation and classification of genotypes in relation to their resistance provides information for producers on the choice of cultivars to be planted.

\section{ACKNOWLEDGEMENTS}

This study was financed in part by the 'Coordenação de Aperfeiçoamento de Pessoal de Nível Superior - Brasil' (CAPES) - Finance Code 001 and 'Rede Interuniversitária para o Desenvolvimento Sucroalcooleiro (RIDESA/PMGCA/UFPR)'. The sixth author received research fellowship from National Council for Scientific and Technological Development (CNPq)/Brazil.

\section{DECLARATION OF CONFLICT OF INTERESTS}

The authors declare no conflict of interest. The founding sponsors had no role in the design of the study; in the collection, analyses, or interpretation of data; in the writing of the manuscript, and in the decision to publish the results.

\section{AUTHORS' CONTRIBUTIONS}

All authors contributed equally for the conception and writing of the manuscript. All authors critically revised the manuscript and approved of the final version.

\section{REFERENCES}

AMORIM, L. et al. Metodologia de Avaliação da Ferrugem da Cana-de-Açúcar (Puccinia melanocephala). Boletim Técnico Copersucar, São Paulo, n.39, p.13-16, 1987.

ARAÚJO, K. L. et al. Genotypic resistance and monitoring of favorability for the occurrence of orange rust in sugarcane. Summa Phytopathologica, v.39, p.271-275, 2013. Available from: <http://www.scielo.br/scielo.php?pid=S010054052013000400007\&script $=$ sci_arttext $>$. Accessed: Feb. 06, 2020. doi: 10.1590/S0100-54052013000400007.

BARBASSO, D. et al. First report of Puccinia kuehnii, causal agent of orange rust of sugarcane, in Brazil. Plant Disease, São Paulo, v.94, n.9, p.1170, 2010. Available from: <https://apsjournals. apsnet.org/doi/10.1094/PDIS-94-9-1170C >. Accessed: Apr. 05, 2019. doi: 10.1094/PDIS-94-9-1170C.

CHAPOLA, R. G. et al. Reaction of sugarcane varieties to orange rust (Puccinia kuehnii) and methods for rapid identification of resistant genotypes. Tropical Plant Pathology, vol 41, p.139-146, 2016. Available from: <https://ink.springer.com/article/10.1007/s40858-0160076-6>. Accessed: Feb. 06, 2020. doi: 10.1007/s40858-016-0076-6.

FAOSTAT. Food and Agriculture Organization os the United Nations. Available from: <http://www.fao.org/faostat/en/\#data/ QC>. Accessed: Feb. 09, 2020.

Ciência Rural, v.50, n.7, 2020. 
GILBERT, R. A. et al. The effect genotype, environmental and time of harvest on sugarcane yields in Florida, USA. Field Crops Research, v.95, p.156-170, 2006. Available from: <https://www. sciencedirect.com/science/article/pii/S0378429005000602>. Accessed: Apr. 05, 2019. doi: 10.1016/j.fcr.2005.02.006.

IDO, O. T. et al. Rust incidence and severity in sugarcane clones at Paraná State, Brazil. Pesquisa Agropecuária Tropical, v.36, n.3, p.159-163, 2006. Available from: <http://agris.fao.org/ agris-search/search.do?recordID=DJ2012038351>. Accessed: Feb. 06, 2020.

KLOSOWSKI, A. C. et al. Reaction of commercial cultivars and assessment date of orange rust of sugarcane. Bioscience Journal, Uberlândia, v.31, n.2, p.489-498, 2015. Available from: $<$ http://www.seer.ufu.br/index.php/biosciencejournal/article/ view/22409>. Accessed: Feb. 06, 2020.

LIMA, L. L. et al. Temperatures and leaf wetness duration on orange rust development in sugarcane (Puccinia kuehnii). Summa Phytopathologica, Botucatu, v.23, n.2, p.132-135, 2017. Available from: <http://www.scielo.br/scielo.php?pid=S0100$54052017000200132 \&$ script $=$ sci_abstract\&tlng $=\mathrm{pt}>$. Accessed: Apr. 16, 2019. doi: 10.1590/0100-5405/1890.

ROTT, P. C. et al. Controlling sugarcane diseases in Florida: a challenge in constant evolution. Proceedings of the International Society of Sugar Cane Technologists, v.29, p.595-600, 2016. Available from: <http://agritrop.cirad. fr/583528/>. Accessed: Apr. 07, 2019.
SANJEL, S. et al. Comparison of progress of brown rust and orange rust and conditions conducive for severe epidemic development during the sugarcane crop season in Florida. Plant Disease, v.103, n.5, p.825-831, 2019. Available from: <https://www.ncbi.nlm.nih. gov/pubmed/30806575>. Accessed: Apr. 06, 2019. doi: 10.1094/ PDIS-05-18-0862-RE.

SOOD, S. et al. Leaf whorl inoculation method for screening sugarcane rust resistance. Plant Disease, v.93. p.1335-1340, 2009. Available from: <https://apsjournals.apsnet.org/doi/abs/10.1094/PDIS-93-121335>. Accessed: Apr. 05, 2019. doi: 10.1094/PDIS-93-12-1335.

SOOD, S. et al. Evaluation of sugarcane clones in the CP-cultivar program for resistance to Puccinia kuehnii, the pathogen of orange rust. Proceedings International Society of Sugar Cane Technologists, v.28.p.1-7,2013.Available from: $<$ https://pubag.nal. usda.gov/pubag/downloadPDF.xhtml?id=56994\& content=PDF $>$. Accessed: Apr. 09, 2019.

URASHIMA, A. S. et al. Effect of pathogen concentrations and period of leaf wetness on orange rust severity in Brazilian sugarcane cultivars. Tropical Plant Pathology, v.43, p.506-513, 2018. Available from: $<$ https://link.springer.com/article/10.1007/s40858-018-0239-8>. Accessed: Feb. 06, 2020. doi: 10.1007/s40858-018-0239-8.

ZHAO, D. et al. Orange rust effects on leaf photosynthesis and related characters of sugarcane. Plant Disease, São Paulo, v.95, n.6, p.640-647, 2011. Available from: $<$ https://apsjournals.apsnet. org/doi/10.1094/PDIS-10-10-0762>. Accessed: Apr. 06, 2019. doi: 10.1094/PDIS-10-10-0762. 